\title{
Rhabdomyolysis in Stuve-Wiedemann syndrome
}

\author{
Pemantah Sandheeah Ramdeny, ${ }_{1}$ Colin Powell, ${ }^{2}$ Mallinath Chakraborty, ${ }^{1,3}$ \\ Louise Hartley ${ }^{1}$
}

'Paediatric Department, University Hospital of Wales, Cardiff, UK

${ }^{2}$ Paediatrics Department, Cardiff and Vale University Health Board, Cardiff, UK ${ }^{3}$ Department of Child Health, Cardiff University, Cardiff, UK

\section{Correspondence to} Dr Louise Hartley, Imhartley@gmail.com

Accepted 19 January 2018

\section{S Linked}

- http://dx.doi.org/10.1136/ bcr-2015-212032

\section{Check for updates}

To cite: Ramdeny PS, Powell C, Chakraborty M, et al. BMJ Case Rep Published Online First: [please include Day Month Year]. doi:10.1136/bcr-2017 222863

\section{SUMMARY}

A 6-month-old male infant with Stuve-Wiedemann syndrome (SWS) presented with an acute respiratory arrest secondary to a rhinovirus respiratory infection from which he was rapidly resuscitated. He developed an acute kidney injury requiring supportive treatment and on day 3 of his illness was noted to have developed severe rhabdomyolysis (creatine kinase level $132040 \mathrm{U} / \mathrm{L}$ (normal <320 U/L)). He was born from consanguineous parents with homozygous mutations in the leukaemia inhibitory factor receptor. He had skeletal dysplasia with metabolic bone disease and episodes of hyperthermia with lactic acidosis. He also had paroxysmal ventricular tachycardia treated with prophylactic propranolol.

This is a case report of a child with SWS who had a febrile illness and epileptic seizures which led to severe rhabdomyolysis outside the context of anaesthesia, and we would like to draw the attention of clinicians to this potential complication.

\section{BACKGROUND}

Stuve-Wiedemann syndrome (SWS) was first proposed in 1971 and was described in two sisters with congenital bowing of the long bones. ${ }^{1}$ It is an autosomal recessive condition consisting of bowing of the long bones, camptodactyly, hypertelorism, micrognathia and hypotonia. The main symptoms are feeding difficulties, respiratory distress and bouts of hyperthermia. ${ }^{23}$ SWS is caused by a mutation in the leukaemia inhibitory factor receptor (LIFR) gene which is a neurotrophic cytokine, one of the interleukin- 6 cytokines. The mutation in the LIFR is a null mutation (a mutation that leads to a loss of function) on chromosome 5p13.1.

\section{CASE PRESENTATION}

This infant of consanguineous parents was born at term, the mother had three previous miscarriages and two live born children including a daughter diagnosed with SWS. ${ }^{5}$ Antenatal scans in this pregnancy showed oligohydramnios, short long bones. An amniocentesis was carried out and the patient was tested for the LIFR gene. The results showed that the patient carried the mutation c.144_145dupGG, p. A49Gfs*6 in exon 3 of the LIFR gene homozygously. This mutation had already been described in his sister's case report. ${ }^{5}$ This frameshift mutation either results in loss of function of the affected allele due to nonsense mediated decay of the mutant mRNA or in a truncated protein with aberrant or no function. Consequently, this mutation was believed to be a causative factor in the pathogenesis of the patient's disease.

His birth weight was $3.2 \mathrm{~kg}$ and his Apgar scores at birth were 7 and 9 . He was noted to have micrognathia, skeletal dysplasia with over-riding second digits, over-riding toes and varus deformities of both legs. He was intubated at 4 hours of age and developed pulmonary hypertension requiring high-frequency oscillatory ventilation and nitric oxide. He also had episodes of hyperthermia, self-resolving sinus tachycardia and hypertension, due to the dysautonomia of SWS.

He was discharged from the neonatal unit at 1 month of age, fed via a nasogastric tube due to an unsafe swallow and taking oral phosphate and vitamin D supplements for his metabolic bone disease. When he was 1 month old, his creatine kinase (CK) was noted to be $1635 \mathrm{U} / \mathrm{L}$. The baseline CK implies an active or dystrophic process and would be compatible with a mitochondrial myopathy, which has been described in association with SWS. ${ }^{6}$

At the age of 6 months, he developed a cough, became hot, clammy and agitated. His parents reported that he had sudden abnormal movements including eye rolling, jerking of all four limbs, with loss of respiratory effort and colour change. His father gave rescue breaths and called an ambulance. On arrival, the paramedic crew gave rectal diazepam and recorded a temperature of $39.5^{\circ} \mathrm{C}$. In the emergency department (ED), he had another seizure which was terminated with intravenous lorazepam, culminating in severe respiratory distress with mixed respiratory and metabolic acidosis, also a lactate level of $5.68 \mathrm{mmol} / \mathrm{L}$.

Rapid sequence induction using thiopentone, rocuronium, an infusion of morphine and midazolam occurred in the ED before being transferred to a paediatric intensive care unit (PICU). His initial sodium was $152 \mathrm{mmol} / \mathrm{L}$, liver function tests (LFTs) showed a raised alanine aminotransferase (ALT) at $336 \mathrm{U} / \mathrm{L}$. ALT repeated 2 days later had risen to $1335 \mathrm{U} / \mathrm{L}$, and all other LFTs were normal-in view of the isolated raised transaminase, serum CK was measured on day 3 and found to be raised at $132040 \mathrm{U} / \mathrm{L}$ (normal range $<320 \mathrm{U} / \mathrm{L}$ ). His renal function tests showed an acute kidney injury (AKI) stage 1 . His urine also tested positive for myoglobin.

Table 1 gives an outline of his blood test results from day 1 to day 7 of his PICU admission.

Initial management in PICU included fluid restriction to $80 \mathrm{~mL} / \mathrm{kg} / \mathrm{day}$, but following the diagnosis of rhabdomyolysis, this was liberalised to 
Unusual association of diseases/symptoms

\begin{tabular}{|c|c|c|c|c|c|c|c|c|c|}
\hline $\begin{array}{l}\text { Blood } \\
\text { tests }\end{array}$ & Day 1 & Day 2 & Day 3 & $\begin{array}{l}\text { Day } 4 \\
\text { (before midday) }\end{array}$ & $\begin{array}{l}\text { Day } 4 \\
\text { (past midday) }\end{array}$ & Day 5 & $\begin{array}{l}\text { Day } 6 \\
\text { (before midday) }\end{array}$ & $\begin{array}{l}\text { Day } 6 \\
\text { (past midday) }\end{array}$ & Day 7 \\
\hline $\mathrm{Na}(\mathrm{mmol} / \mathrm{L})$ & 155 & 155 & 157 & 143 & 148 & 147 & 147 & 146 & 143 \\
\hline $\mathrm{K}(\mathrm{mmol} / \mathrm{L})$ & 3.9 & Haemolysed & 4.9 & 4.7 & Haemolysed & 4.0 & 5.3 & 3.3 & 5.2 \\
\hline Urea (mmol/L) & 8.6 & 7.2 & 3.7 & 3.7 & 3.2 & 4.1 & 6.1 & 4.0 & 3.5 \\
\hline Creatinine $(\mu \mathrm{mol} / \mathrm{L})$ & 25 & 22 & 23 & 15 & 14 & 19 & 19 & 13 & 16 \\
\hline $\begin{array}{l}\text { ALT } \\
\text { (U/L) }\end{array}$ & 336 & - & 1142 & 1335 & 960 & 955 & 912 & 781 & 756 \\
\hline $\begin{array}{l}\text { CK } \\
(U / L)\end{array}$ & - & - & 132040 & 112640 & 45300 & 36980 & 22620 & 10860 & 8260 \\
\hline $\begin{array}{l}\text { Maximum level of } \\
\text { lactate (mmol/L) }\end{array}$ & 5.68 & 3.0 & 5.1 & 4.9 & 10.1 & 13.3 & 1.7 & 1.1 & 11.5 \\
\hline
\end{tabular}

$\mathrm{ALT}$, alanine aminotransferase; $\mathrm{CK}$, creatine kinase; PICU, paediatric intensive care unit .

$120 \mathrm{~mL} / \mathrm{kg} /$ day. His renal function returned to normal after 7 days. His serum CK gradually returned to his baseline levels. He was treated with intravenous cefotaxime for 7 days for presumed sepsis, but blood cultures were subsequently negative. His nasopharyngeal aspirates were positive for rhinovirus. The precipitant to the respiratory arrest was thought to be either the rhinovirus infection, a paroxysmal tachycardia or a seizure due to hypernatraemia or hyperthermia. He was extubated on day 4 and was noted to have stiffness of all four limbs. CT scan of his head showed no significant changes. MRI scan of his head showed attenuated diffusion in the hemispheric white matter bilaterally with some changes on the T2-weighted imaging, suggestive of a metabolic condition as opposed to an acquired injury.

\section{OUTCOME AND FOLLOW-UP}

He made a complete recovery from his episode of rhabdomyolysis with his serum ALT, lactate, renal function and CK returning to his baseline levels. Three months after the acute event, he was noted to have an unsafe swallow; however, he was developing head control and attempting to roll. His head circumference and weight were both following the 0.4 th centile.

\section{DISCUSSION}

Cases of SWS with malignant hyperthermia leading to rhabdomyolysis in the context of anaesthesia have been reported previously. ${ }^{78}$ This is the first case report to the best of our knowledge of SWS associated with severe rhabdomyolysis outside the context of anaesthesia. The characteristic feature of rhabdomyolysis is a rise in the level of CK as well as other serum muscle enzymes. One of the other findings is the reddish-brown urine of myoglobinuria. However, as this feature may only be observed in half of cases, absence of myoglobinuria does not preclude a diagnosis of rhabdomyolysis. ${ }^{9}$

Malignant hyperthermia is normally caused by volatile anaesthetic agents such as halothane, sevoflurane, desflurane or depolarising muscle relaxants such as suxamethonium, used predominantly for the induction of general anaesthesia. ${ }^{10} 11$ In this case, anaesthetic drugs which were considered safe to prevent the occurrence of malignant hyperthermia such as thiopentone, midazolam and non-depolarising muscle relaxants agents such as rocuronium were used for rapid sequence induction. ${ }^{12}$ There are no specific anaesthetic agents recommended, or for which there are absolute contraindications, in SWS but extreme caution is vital when administering anaesthetic agents. ${ }^{13}$ Furthermore, in this case, the patient did not require treatment with dantrolene, cold intravenous fluids and cooling measures, ${ }^{10}$ which suggests that the rhabdomyolysis was not due to malignant hyperthermia.
He was also given intravenous cefotaxime for 7 days during his hospital admission. Cefotaxime has not been implicated in the pathogenesis of rhabdomyolysis, and there is a case report of a patient with a viral illness who developed severe rhabdomyolysis and was treated empirically with intravenous cefotaxime with resolution of the rhabdomyolysis. ${ }^{14}$ Our patient's CK on day 3 of his illness was $132040 \mathrm{UL}$ and gradually came down to $8260 \mathrm{U} / \mathrm{L}$ while he was being treated with intravenous cefotaxime.

Common viral infections are one of the common causes linked to rhabdomyolysis in vulnerable patients, progressing to high core body temperatures as well as an increase in the level of circulating proinflammatory cytokines and chemokines. ${ }^{15-17}$

The pathogenesis of rhabdomyolysis in the context of SWS is thought to be due to a defect of the mitochondrial respiratory chain. ${ }^{18}$ This has been demonstrated by Chabrol et al ${ }^{6}$ who substantiated their hypothesis by performing enzymatic measures in muscle biopsies. Their results demonstrated that in patients with SWS, there was reduced activity of complex I (nicotinamide adenine dinucleotide ubiquinone reductase) and complex IV (cytochrome c oxidase) of the mitochondrial respiratory chain.

We postulate that the occurrence of rhabdomyolysis results from a failure of energy production leading to fibre necrosis ${ }^{17}$ as well as the underlying dystrophic or mitochondrial process. ${ }^{6}$ The inability of energy production due to a defect in complexes I and IV of the mitochondrial respiratory chain ${ }^{6}$ causes the level of ATP to fall which results in $\mathrm{Na} / \mathrm{K}$-ATPase and Ca-ATPase pump dysfunction. This leads to an increase in the intracellular concentration of calcium and activation of the calcium-dependent neutral proteases causing injury to the sarcolemma. ${ }^{19} 20$ As a consequence of the necrosis of the skeletal muscle fibres, there is release of toxic cellular content (CK), myoglobinuria and AKI. ${ }^{6} 19$

However, as there are almost always multiple factors contributing to rhabdomyolysis, ${ }^{21}$ it is possible that the patient's seizures, hyperthermia, upper respiratory tract infection and resuscitation might have contributed to the development of rhabdomyolysis.

Rhabdomyolysis is associated with a $10 \%$ mortality rate which is increased if the condition is linked to renal failure 22 or cardiac arrhythmia leading to cardiac arrest secondary to hyperkalaemia. ${ }^{23}$ In this case, rhabdomyolysis as a complication of SWS had not initially been considered by the treating clinicians, and it was only 3 days after the event that a serum CK was measured, then $132040 \mathrm{U} / \mathrm{L}$. Supportive treatment by increasing the total intravenous fluid maintenance helped to resolve the rhabdomyolysis. 


\section{Learning points}

- We recommend clinicians to be alert to the possibility of rhabdomyolysis in the context of Stuve-Wiedemann syndrome (SWS).

- Febrile illness may be a trigger for rhabdomyolysis and we recommend considering measuring serum creatine kinase (CK) in febrile children with SWS.

- In the intensive care setting, it is crucial to think of performing a serum CK level in children with SWS in order to give the appropriate fluid management to prevent the complications associated with rhabdomyolysis.

Contributors Original concept was by LH and PSR. All four authors (PSR, MC, $C P, L H)$ contributed to the writing of the manuscript, reviewing, editing and final approval of the manuscript.

Competing interests None declared.

Patient consent Guardian consent obtained.

Provenance and peer review Not commissioned; externally peer reviewed.

C BMJ Publishing Group Ltd (unless otherwise stated in the text of the article) 2018. All rights reserved. No commercial use is permitted unless otherwise expressly granted.

\section{REFERENCES}

1 Stüve A, Wiedemann HR. Congenital bowing of the long bones in two sisters. Lancet $1971 ; 2: 495$

2. Kozlowski K, Tenconi R. Stüve-Wiedemann dysplasia in a $31 / 2$-year-old boy. Am J Med Genet 1996:63:17-19.

3 Cormier-Daire V, Munnich A, Lyonnet S, et al. Presentation of six cases of StüveWiedemann syndrome. Pediatr Radiol 1998:28:776-80.

4 Dagoneau N, Scheffer D, Huber C, et al. Null leukemia inhibitory factor receptor (LIFR) mutations in Stuve-Wiedemann/Schwartz-Jampel type 2 syndrome. Am J Hum Genet 2004;74:298-305
5. Knipe M, Stanbury $R$, Unger $S$, et al. Stuve-Wiedemann syndrome with a novel mutation. BMJ Case Rep 2015;2015:pii: bcr2015212032. doi: 10.1136/bcr-2015212032

6 Chabrol B, Sigaudy S, Paquis V, et al. Stüve-Wiedemann syndrome and defects of the mitochondrial respiratory chain. Am J Med Genet 1997;72:222-6.

7 Seay AR, Ziter FA. Malignant hyperpyrexia in a patient with Schwartz-Jampel syndrome. J Pediatr 1978;93:83-4.

8. Fowler WM, Layzer RB, Taylor RG, et al. The Schwartz-Jampel syndrome. Its clinical, physiological and histological expressions. J Neuro/ Sci 1974;22:127-46.

9. Miller V. Clinical manifestations and diagnosis of rhabdomyolysis, 2017.

10. Rosenberg H, Davis M, James D, et al. Malignant hyperthermia. Orphanet J Rare Dis 2007;2:21. 10.1186/1750-1172-2-21.

11 Groom L, Muldoon SM, Tang ZZ, et al. Identical de novo Mutation in the Type 1 Ryanodine Receptor Gene Associated with Fatal, Stress-induced Malignant Hyperthermia in Two Unrelated Families. Anesthesiology 2011:115:938-45.

12 Malignant Hyperthermia Association of United State.https://www.mhaus.org/ healthcare-professionals/be-prepared/safe-and-unsafe-anesthetics/

13 Driessen J, Al-Gazali L, Pizones J, et al. Anaesthesia recommendations for patients suffering from Stüve-Wiedemann syndrome. http://www.orpha.net/consor/cgi-bin/ OC_Exp.php?lng=EN\&Expert $=3206$

14 D'Silva D, Hewagama S, Doherty R, et al. Melting muscles: novel H1N1 influenza A associated rhabdomyolysis. Pediatr Infect Dis J 2009;28:1138-9.

15 Hotamisligil GS, Shargill NS, Spiegelman BM. Adipose expression of tumor necrosis factor-alpha: direct role in obesity-linked insulin resistance. Science 1993;259:87-91.

16 Weisberg SP, McCann D, Desai M, et al. Obesity is associated with macrophage accumulation in adipose tissue. J Clin Invest 2003;112:1796-808.

$17 \mathrm{Xu} \mathrm{H}$, Barnes GT, Yang Q, et al. Chronic inflammation in fat plays a crucial role in the development of obesity-related insulin resistance. J Clin Invest 2003:112:1821-30.

18 Munnich A, Rötig A, Chretien D, et al. Clinical presentations and laboratory investigations in respiratory chain deficiency. Eur J Pediatr 1996;155:262-74.

19 Sauret JM, Marinides G, Wang GK. Rhabdomyolysis. Am Fam Physician 2002:65:907-12.

20 Shapiro ML, Baldea A, Luchette FA. Rhabdomyolysis in the intensive care unit. $J$ Intensive Care Med 2012;27:335-42.

21 Zutt R, van der Kooi AJ, Linthorst GE, et al. Rhabdomyolysis: review of the literature. Neuromuscul Disord 2014;24:651-9.

22 Cervellin G, Comelli I, Lippi G. Rhabdomyolysis: historical background, clinical, diagnostic and therapeutic features. Clin Chem Lab Med 2010;48:749-56.

23 Luck RP, Verbin S. Rhabdomyolysis: a review of clinical presentation, etiology, diagnosis, and management. Pediatr Emerg Care 2008;24:262-8.

Copyright 2018 BMJ Publishing Group. All rights reserved. For permission to reuse any of this content visit

http://group.bmj.com/group/rights-licensing/permissions.

BMJ Case Report Fellows may re-use this article for personal use and teaching without any further permission.

Become a Fellow of BMJ Case Reports today and you can:

- Submit as many cases as you like

- Enjoy fast sympathetic peer review and rapid publication of accepted articles

- Access all the published articles

- Re-use any of the published material for personal use and teaching without further permission

For information on Institutional Fellowships contact consortiasales@bmjgroup.com

Visit casereports.bmj.com for more articles like this and to become a Fellow 